\title{
DIGITALIZATION OF CREATIVE MARKETS: EFFORTS TO DEVELOP FAMILY ECONOMIC RESILIENCE IN LAMPUNG
}

\author{
Siti Zulaikha ${ }^{1}$, Enny Puji Lestari ${ }^{2}$, Titut Sudiono ${ }^{3}$, Maulana Husen $\mathrm{S}^{4}$ \\ 1,2,3,4|AIN Metro Lampung \\ Jl. Ki Hajar Dewantara No.15A, Kota Metro, Lampung \\ Email: ${ }^{1}$ sitizulaikha@metrouniv.ac.id, ${ }^{2}$ ennypujilestari@metrouniv.ac.id, \\ ${ }^{3}$ sudiono24@gmail.com, ${ }^{4}$ maulanahs070@gmail.com
}

\begin{abstract}
This study aims to analyze the digitalization of the creative market on the economic growth of the family and to see the role of the family in the economic resilience of the community. This research uses a qualitative method with a case study approach that is field research. Sources of data from creative markets in two districts, namely Metro City and East Lampung. The results of the study indicate that the creative market is able to encourage family economic growth towards a more established direction, and build family relationships in economic resilience. The digitalization of the creative market has also been proven to be able to improve the family's economy, such as meeting secondary and tertiary needs, education savings and retirement savings, fulfilling education costs, and fulfilling kitchen utensils. Another indication of the progress of the family economy is also marked by the development of fundamental aspects that support the creative economy, such as creativity, innovation, and invention. These three aspects can then affect creative business opportunities that are more wide open, more diverse livelihoods, easier to find additional income, souvenirs typical of tourist areas, and the title of a tourist city.
\end{abstract}

Keywords: Digitalization; Creative Market; Economic Resilience

\begin{abstract}
Abstrak: Penelitian ini bertujuan untuk menganalisis digitalisasi pasar kreatif terhadap pertumbuhan ekonomi keluarga dan melihat peran serta keluarga dalam ketahanan ekonomi masyarakat. Riset ini menggunakan metode kualitatif dengan pendekatan studi kasus yang bersifat penelitian lapangan. Sumber data dari pasar kreatif yang ada di dua kabupaten yaitu Kota Metro dan Lampung Timur. Hasil penelitian menunjukkan bahwa pasar kreatif mampu mendorong pertumbuhan ekonomi keluarga ke arah yang lebih mapan, dan terbangun relasi keluarga dalam ketahanan ekonomi. Digitalisasi pasar kreatif juga terbukti mampu meningkatkan ekonomi keluarga seperti pemenuhan kebutuhan sekunder dan tersier, tabungan pendidikan dan tabungan hari tua, pemenuhan biaya pendidikan, dan pemenuhan peralatan dapur. Indikasi lain kemajuan ekonomi keluarga juga ditandai dengan berkembangnya aspek-aspek fundamental yang mendukung ekonomi kreatif, seperti kreativitas, inovasi, dan penemuan. Ketiga aspek tersebut selanjutnya dapat mempengaruhi peluang bisnis kreatif yang lebih terbuka lebar, mata pencaharian yang lebih beragam, lebih mudah untuk mencari penghasilan tambahan, oleh-oleh khas daerah wisata, dan gelar kota wisata.
\end{abstract}

Kata kunci: Digitalisasi; Pasar Kreatif; Ketahanan Ekonomi 


\section{Introduction}

A market is a place for buyers and sellers where the market share carries out trade transactions according to their needs. It is different from the creative market;creative economic actors develop creative assets by prioritizing ideas and knowledge from human and natural resources as the most critical production factors.

Creative economy actors in driving the economy through an intelligent, innovative, and creative design dramatically affect the welfare of the community, especially micro, small and medium enterprises. Creative economy opportunities maximize the potential and opportunities for economic growth and development; in line with his opinion Purnomo in his book Creative Economic by AnggriPuspita Sari et al, said that the creative economy is the use of creativity the creation of innovation through technology development. ${ }^{1}$

ArifYahya first offered the digital concept; he said that digital destinations are promotional media. $^{2}$ Where in the management of the creative market, there is interference with digital concepts as a medium to promote the creative market. In line with Sunanik's opinion quoted by Ikhwanus Sofa, the creative economy is believed to answer the challenges of short and medium-term problems. ${ }^{3}$

Therefore, looking at the current development of the digitalization market, economic actors come from small and medium businesses, this is very helpful for the existence of a creative need that involves the local

\footnotetext{
${ }^{1}$ Anggri Puspita Sari et al., Ekonomi Kreatif (Yayasan Kita Menulis, 2020), p. 4.

${ }^{2}$ Slamet Mulyana, Meria Octavianti, and Nadila Zahara Faradysa, "Pengelolaan Media Sosial Sebagai Media Promosi Pasar Digital Cikundul Sukabumi,” No. 1 (2019), p. 50.

3 Ikhwanus Shofa, "Pertumbuhan Dan Strategi Pengembangan Ekonomi Kreatif Kota Malang," Jurnal Pangrita 1, No. 1 (2018), p. 76.
}

community in helping the financial resilience of the community who have contributed to the economy so that it has a significant impact on the creation of a positive, innovative, and creative business climate which are the competitive advantages of a nation. ${ }^{4}$

Lampung is one of the drivers of the creative economy, based on statistical data that the number of creative economy businesses is 178,511 , spread from various regions in Lampung, namely by City/Regency, $1.67 \%$ West Lampung, 6.23\% South Lampung, 5.58\% Central Lampung, 5.06\% East Lampung, 4.81\% Metro City, Bandar Lampung City 58.05\%, 4.16\% Pesawaran, 2.47\% Tanggamus, $5.84 \%$ Pringsewu. ${ }^{5}$

Data from creative business actors in Lampung shows that public interest in coming up with innovative ideas has become an excellent magnet for creative market players to develop regional potential and human resources, thereby contributing to economic resilience, especially families.

The author focuses more on the creative economy in the Culinary, Craft, fashion, and music sectors in this study. From the distribution of innovative economy sub-sector data, it shows $14.68 \%$ culinary, $2.60 \%$ craft, $4.42 \%$ fashion and $7.01 \%$ music. $^{6}$ The intensity of the creative industry is a breakthrough in increasing the imagination of human resources, so it is necessary to study its growth and development, which is caused by the existence of family relations in maintaining economic resilience that depends on the value of digitalization carried out. ${ }^{7}$

\footnotetext{
${ }^{4}$ DR Mari Elka Pangestu, "HasilKonvensi Pengembangan Ekonomi Kreatif 2009-2015," June 2008, p. 27.

5 Badan Ekonomi Kreatif, Infografis Sebaran Pelaku Ekonomi Kreatif (Jakarta, 2019), p. 25.

${ }^{6}$ Badan Ekonomi Kreatif, Infografis Sebaran Pelaku Ekonomi Kreatif (Jakarta, 2019), p. 25

7 Ansori, Aan. "Digitalisasi Ekonomi Syariah." Islamiconomic: Jurnal Ekonomi Keuangan Dan Bisnis Islam 7, No. 1 (2016), p. 54
} 
Metro and East Lampung are one of the focuses of the author's research where the existence of a creative market by looking at data is $5.06 \%$ of East Lampung, $4.81 \%$ of Metro City with the creative economy subsector, the highest percentage of which in Lampung is culinary $14.68 \%{ }^{8}$ Therefore, the development of the creative economy of the digital market needs to be studied whether digitalization of the creative market can encourage family economic growth. It is also necessary to examine how family relations are involved in the financial resilience of the community.

The purpose of this study is to analyze the digitalization of the creative market on the economic growth of the family and to see the role of the family in the financial resilience of the community.

\section{Methodology}

Based on the research location, this research will focus on creative market traders in the Metro City and East Lampung. Therefore, this research is included in field research. A biblioticanalysis is only used to define digitization and economic resilience in the creative market. Meanwhile, the data that is processed and presented is descriptive narrative research. Therefore, this research is included in the type of qualitative research. There is no numerical data that is the subject of the study here.

Primary data sources were obtained from three creative market traders, two operators, buyers with a random system, and one tourism office. The focus of the study is divided into one city and one district. The chosen ones are Metro City and East Lampung Regency.

\footnotetext{
${ }^{8}$ Badan Ekonomi Kreatif, Infografis Sebaran Pelaku Ekonomi Kreatif (Jakarta, 2019), p. 25
}

Buyers or consumers are selected by random sampling with the following considerations: (i) residence; (ii) formal educational background of traders; (iii) culinary traders.

Secondary sources are all data in magazines, newspapers, journals, and books that have discussed the creative market that uses digitalization to develop economic resilience.

Data collection techniques used are observation, interviews, and documentation. Statements are employed to observe the behavior of creative market traders. Interviews are used to explore data more deeply. Meanwhile, focused group discussion is used to finalize and strengthen research findings.

This research is descriptive-analytical; the writer goes through two stages. In the first stage, the writer reviews several pieces of literature and then determines the research setting. While the second stage, the writer conducts field research in the form of a comprehensive assessment, both by conducting observations and interviews with informants, on the subject of the study. And analyzing the field findings and writing the ethnographic strategy for developing economic resilience for creative market traders.

The author gets some creative market references in East Lampung Regency and Metro City at the literature review stage. The authors get directly from interviews withseveral informants.

\section{Discussion}

\section{A. Digitalization of Creative Markets Can Encourage Family Economic Growth}

The existence of the creative market by looking at $5.06 \%$ of East Lampung and $4.81 \%$ of Metro City with the highest percentage in Lampung, namely the culinary sub-sector is at $14.68 \%$. Creative market packaging through digital media is very effective in the 
current digital era, where Population growth has coincided with unparalleled technological developments.

\section{a. Digital Media Scopes}

The digitalization of creative markets in East Lampung and Metro City increases with the web or social networks Facebook, WhatsApp, and Instagram, which can bring together sellers and buyers at the targeted marketplace. The digital media used by the creative market where the research is conducted the Payungi, Paruk Mas, Pak Tejo, and the WarungMacan creative market. From Facebook data, the number of followers is as follows;

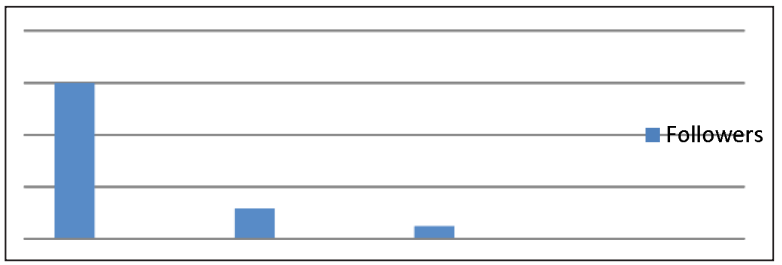

Courtesy: Facebook

The data above shows that the most social media followers on Facebook are Payungimarketwith 1,501 followers, followed by Paruk Mas Market with 294 people, and Pak Tejo Creative Market with 122 people. The WarungMacan market does not have a Facebook account like other creative markets.

In addition to Facebook, there is Instagram which is used as one of the digital media in promoting the creative market, which is as follows;

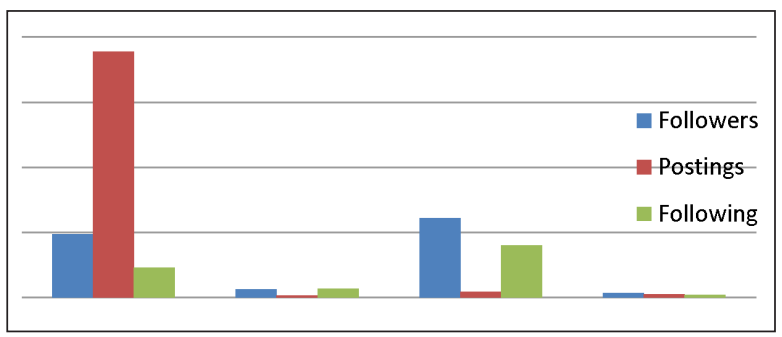

Courtesy: Instagram
From this data, it can be seen that the followers of the creative market on Instagram accounts are mostly Pak Tejo creative market with a total of 2,436 people, then there is the Payungimarket with 1,950 followers, 240 people of Paruk Masmarket, and 126 PawangMacan market. The number of followers on Instagram does not affect the number of visitors. However, the distribution of products in viral marketing among consumers is to become a magnet for visitors by spreading posts sent by the team of creators in the digitalization category, which can be felt by visitors so that they have an efficient and practical impact, open networking, conduct economic transactions and can provide magnetic power. Visitors come to the creative market to buy culinary food according to their wishes. As illustrated in the data above, the Payungimarketposts are 7,562, most of the four existing creative markets.

The use of digital marketing benefits the home industry. It is also implemented to increasebrand awareness ${ }^{9}$, considered effective and efficient in facilitating product promotion and introduction to the broader community so that product branding can be built.

In addition, the collaboration of high concept and high touch has made innovation an artistic and emotional beauty in creation, creating opportunities that can help people support the economy with human interaction that gives meaning to the visitors who come to the creative market and for traders. ${ }^{10}$

${ }^{9}$ Siti Alvi Sholikhatin, Wanda Fitrianingsih, and Sahira Dhiyaulhaq, "Pelatihan Digital Marketing Bagi Anggota Nasyiatul Aisyiyah Purbalingga Dalam Menghadapi Era Pasar Global Dan Pengembangan Industri Kreatif” 4 (n.d.), p.850.

${ }^{10}$ Azizah, Siti Nur, and Muhfiatun. "Pengembangan Ekonomi Kreatif Berbasis Kearifan Lokal Pandanus Handicraft dalam Menghadapi Pasar Modern Perspektif Ekonomi Syariah (Study Case di Pandanus Nusa Sambisari Yogyakarta)." Aplikasia: Jurnal Aplikasi Ilmuilmu Agama 17, No. 2 (February 12, 2018), p. 63. https:// doi.org/10.14421/aplikasia.v17i2.1273. 
The role of the creative economy, which has its characteristics, especially in each market, has become a culture in economic development in society. This has implications for aspects that are the basis for supporting the creative economy, namely:

\section{1) Creativity}

As something unique, fresh, and acceptable to the general public. Because creativity is something that arises from something that already exists into something that has never existed. This can be seen from the creative markets in Metro City, namely Payungi, Pak Tejo, and Paruk Mas, as well as the creative markets in East Lampung, namely WarungMacan or PawangMacan.

The market location has been transformed into a place for photo and culinary spots, crafts, music, and narrow streets that have been transformed into tourist destinations that can be visited in creative markets in Metro City and East Lampung.

The creativity carried out by the creative market is by creating Instagram and Facebook accounts created by thePayungi market creator team in creating content, the themes and contents that must be poured must be different, a strategy is needed in uploading content in each event, namely traditional culinary, photo spots and places that can be visited in the Panyungi market, then the accounts are uploaded every day in the morning and evening. ${ }^{11}$

The creativity carried out by ParukMas market is by uploading creative activity flyers that are photo documentation of photo spots there and traditional food menus. ${ }^{12}$ Meanwhile,

${ }^{11}$ M. Imam Khoiri, Interview About Digitalization of Creative Markets in Encouraging Family Economic Growth, September11, 2021

${ }^{12}$ Hidayat, Interview About Digitalization of Creative Markets in Encouraging Family Economic Growth, September11, 2021 in Pak Tejo market, creativity can be seen in the craftsmen and street musicians who decorate each event. ${ }^{13}$ In addition, there is a PawangMacanmarket that has the invention to hold children's coloring competitions and create accounts on social media with culinary food menus. ${ }^{14}$

It can be seen that there is creativity that depicts art and culture from a natural resource that is transformed into a place where traders and buyers feel comfortable visiting; this becomes a magnet for market share to enjoy the beautiful panorama of nature with a village atmosphere that is dense with culinary specialties from Indonesia that market.

\section{2) Innovation}

A transformation from an idea based on creativity to a product that provides added value and benefits for the surrounding community who feel and impact economic growth and new jobs. Payungi, Pak Tejo, Paruk Mas, and PawangMacan markets are innovations in producing products. The benefits can be handled directly at every trade event, or those who don't hold merchandise. This has a significant impact on encouraging the family's economic growth.

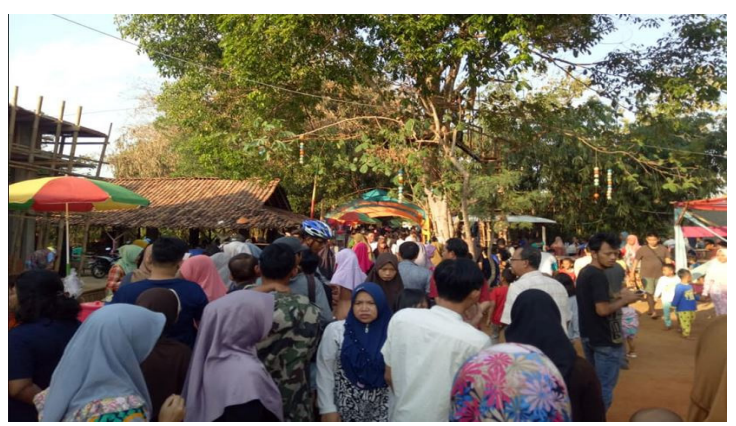

Location: Payungimarket

${ }^{13}$ Linang Kharisma, Interview with the Creative Team about Digitizing Creative Markets in Encouraging Family Economic Growth, September 2021.

14 Atik Nurakhimah, Interview with the Creative Team about Digitizing Creative Markets in Encouraging Family Economic Growth, September 2021. 
The picture shows that every traditional food event in the Payungimarket is in great demand by visitors; this is very inspiring for many young people, communities, and activists. In building communication with the district, a collaboration by improving creativity can increase capabilities. ${ }^{15}$ No less attractive, other markets are also following in the footsteps of the Panyungi market.

\section{3) Contrivance}

The emphasis in this aspect is to create something that has never existed with a unique characteristic that can be useful for the general public. The discovery of the existence of a creative market has become a particular color for the local village community, which has implications for the sub-district and can attract guests from other areas to visit because there is a creative market that is directly adjacent to the community and very responsive to the environment, with different characteristics.
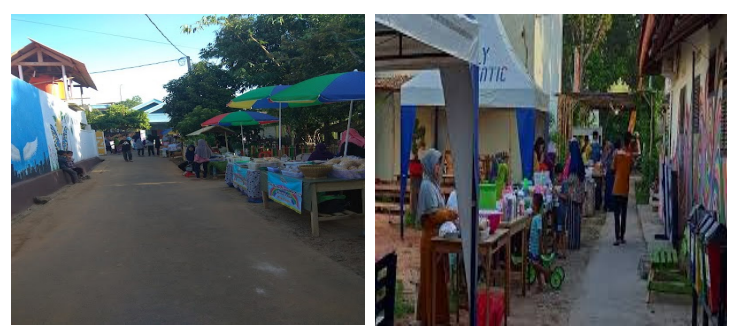

Location: Pak Tejo Creative Market \& Payungi Creative Market

The picture above is located in Pak Tejocreative market and Panyungi market, showing existing roads that can be used for trading; this provides innovation in a place that can be managed into a creative need. It is different from the Paruk Mas market, which uses the land of the gardens to be

15 Dwi Nugroho, Interview About Digitalization of Creative Markets in Encouraging Family Economic Growth, September 2021. transformed into a culinary place and a photo hotspot. The land used for the mat is rented out to traders. So there are benefits that garden owners and traders feel.

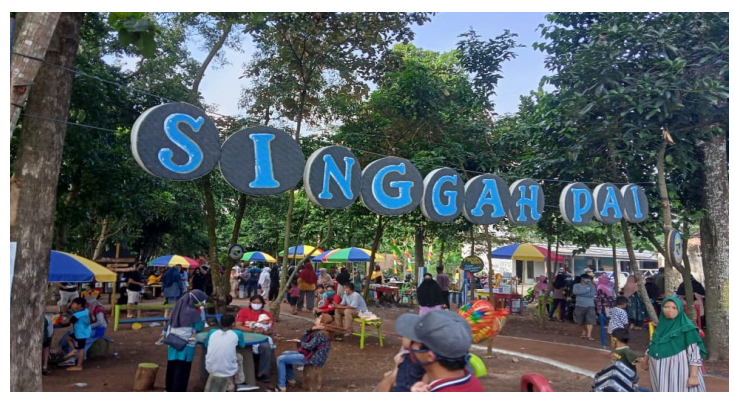

Location: Paruk Mas Market

A creative market is a unique invention with the use of natural resources and supported by human resources so that there is an innovative market that drives the millennial generation by using digitalization, which has transformed the usual place into a place that many people visit.

\section{b. Creative Market Management Strategy}

Managing the digitalization of creative markets prioritizes management aspects with managerial so that they can survive and compete in the market world. The management of digital needs carried out by Payungi Market, Paruk Mas Market, Pak Tejo Market, and WarungMacan Market in its direction is in line with SlametMulyana's opinion and was written in a journal entitled "Social Media Management as Promotional Media for Cikundul Sukabumi Digital Market," ${ }^{16}$ creative market management by making several efforts, namely carrying out pre-events before the inauguration of the digital creative market, which is filled with activities in the form of competitions, and many morein addition, creating an official creative market

${ }^{16}$ Slamet Mulyana, Meria Octavianti, and Nadila Zahara Faradysa, "Pengelolaan Media Sosial Sebagai Media Promosi Pasar Digital Cikundul Sukabumi,” No. 1 (2019), p.18. 
account and designing social media content related to routine activities every week in the digital creative market.

\section{c. Creative Market Digitization Development Strategy}

Creative market development prioritizes the use of internet technology. Technological development can increase productivity so that people's economic activities cannot be separated from the development of digital systems. ${ }^{17}$ This activity was carried out by the creative market activists of Payungi market, Paruk Mas Market, Pak Tejo Market, and WarungMacan Market. The existence of internet technology lowers transaction costs, so the products offered will be more ogled by the public with packaged content that makes people interested in buying them and visiting the destination.

The development carried out is by increasing creative and innovative human resources, growing products characterized by local wisdom that have global competitiveness, developing and strengthening environmentally friendly technologies, developing the availability of local materials, optimizing the use of an innovative product, and opening up access and maintaining networked connections.

\section{d. Creative Market Digitization Marketing Strategy}

Marketing is a form of planning in maximizing the creative market by digitizing. In this study, the authors found that Payungimarket has an Instagram account @pasarkreatif_ tejoagung, @kampungbudaya_tebas, @pakare_,

$17 \mathrm{Ni}$ Ketut Sari Adnyani and Dewa Ayu Eka Agustini, "Digitalisasi Sebagai Pemulihan Perekonomian di Sektor Kerja Dalam mendukung Kebangkitan UMKM di Provinsi Bali," Jurnal Pengabdian Masyarakat Media Ganesha Fhis 1, No. 2 (2020), p. 93. riverswidecamp_, and @kampungkopipayungi. In contrast, Pak Tejo market has an Instagram account@paktejo. Besides that, Paruk Mas market has an Instagram account @parukmas, and WarungMacanmarket has an Instagram account @pawangmacan, optimizing Facebook and advertisement on another website, collaborating with the online community, and using respective creative markets.

Therefore, the digitalization marketing strategy has offered products supported by the creative potential of using digital media so that the target of marketing an innovative product can be socialized to the public as desired consumers.

\section{B. Family Relations in Community Economic Resilience}

Creating economic resilience on a macro scale starts from a smaller scope, namely at the family level. Solid relationships strengthen socializing activities in the community to build family economic resilience. ${ }^{18}$

Economic resilience relates to the ability of the community to use available resources to meet basic needs through strategies with social media. Therefore, digitalization plays a strategic role in fulfilling economic security, especially for families. The data on creative market culinary traders in Metro City and East Lampung are as follows;

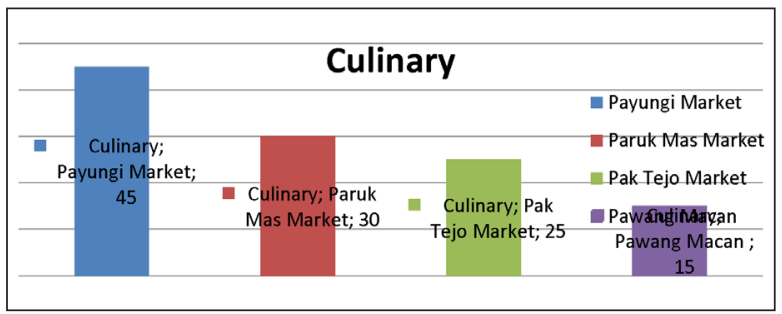

Creative Market Culinary Traders

${ }^{18}$ Rofaida, Rofi, Suryana, Asti Nur Aryanti, and Yoga Perdana. "Strategi Inovasi pada Industri Kreatif Digital: Upaya Memperoleh Keunggulan Bersaing pada Era Revolusi Industri 4.0.” Jurnal Manajemen dan Keuangan 8 , no. 3 (June 11, 2020), p. 42-44. 
From the culinary traders' data above, it is clear that the Payungimarket has more culinary market traders; namely, there are 45 traditional food traders, compared to the PawangMacan market, which only has 15 culinary traders. The cooperative relations carried out by the community and families can be seen from the number of creative market traders who can survive in the concept of the community's economic resilience movement. Therefore, it is necessary to look at the approach taken.

The approach is carried out by taking into account the movement's roadmap, thus characterizing the four indicators of economic resilience. The indicators of community economic resilience in the family are as follows;

\section{a. Economic Stability}

Unlimited support from family and closest people has a positive impact on the psyche of a person or group of people. Unlimited support has various forms, both verbal and deed. As a role model for the creative market in Lampung province, Payungi has had a higher level of empowerment than other innovative markets. The creative atmosphere that looks more lively from the administrators, traders, communities, communities, and government and educational institutions, both during market events and weekdays, makes the circulation of money evenly distributed in the area around Payungi. Likewise with Pak Tejo, through the savings approach, which was initially used to minimize the practice of usury in TejoAgung and the procedure by strengthening mindset as marketers, have made economic resilience and stability in these two creative markets stronger.

Strong indications of economic stability in these two markets are evidenced by the fact that each trader has a certain amount of money in a savings account managed by a third party, carries out education or lectures comfortably, and the continuity of family life is more secure with new livelihoods, thereby opening up a new door of income at the micro household level.

\section{b. Market Efficiency}

The progress of market efficiency refers to product marketing activities and the reach of the target market achieved. Paying, with stakeholders who have diverse backgrounds and are supported by collaboration with the community, makes visits to Payungi's social media accounts more complex. Payungi managed to take advantage of this complex public by segmenting it into specific subgroups by creatingnotable social media accounts, such as Payungi Wedding, which serves decorations, Payungi Book Store, Payungi Ethnic, Payungi Car, and many more. That way, the built culture tries to absorb as many visitors as possible through this segment. Likewise, with Paruk Mas, the concept of market efficiency allows market members to market their merchandise under the name Paruk Mas so that their marketing reach is more comprehensive when compared to one marketer's account.

\section{c. Good Management}

An indicator of good management is the growing awareness of stakeholders about their roles and functions in the organization. Contributions made by stakeholders are a form of complete understanding of the responsibility and feeling of belonging to the organization. ${ }^{19}$ In general, good management is built by strengthening internal and external relationships; for example, Payungi, on a narrow scale, integrates stakeholders, while on a broader

19 Firdausy, Carunia, ed. Strategi Pengembangan Ekonomi Kreatif di Indonesia. (Jakarta: Yayasan Pustaka Obor Indonesia, 2018), p. 56 
scale, integration is carried out with district/ city officials and the creative community in Lampung. In the case of Pak Tejo, the market secretary also shows the feeling of belonging to the organization. As an active member of the Indonesian National Police, he channels his authority by inviting street musicians to enliven Pak Tejo with music. Likewise, with the PawangMacan, good management creates a feeling of belonging to the organization as indicated by the contribution of the Village Government, Farmers' Group Associations, Women's Farmers' Groups, and educational institutions. Each has the same vision, together to build a village and think of solutions to phenomena that occur in the community.

\section{d. Social Development Planning}

The next indicator of economic resilience is social development planning. Payungi represents this indicator with 'driver-friendly programs, women's environmental studies, and child-friendly programs. Each of them targets social development in the segment of village empowerment, women's rights, and education methods for children. Meanwhile, Pak Tejo represents this indicator through a marketer program for all residents of RT 06 to suppress usury transactions and increase citizen awareness to be technology literate and an effort to improve the standard of living together.

\section{Conclusion}

The digitalization of the creative market is proven to encourage positive family economic growth, such as the fulfillment of secondary and tertiary needs, education savings and old age savings, the satisfaction of tuition fees, fulfillment of kitchen utensils, and many more. Another indication of family economic growth is also marked by developing fundamental aspects that support the creative economy, such as creativity, innovation, and invention. These three aspects can further influence creative business opportunities that are more wide open, more diverse livelihoods, easier to find additional income, souvenirs typical of tourist areas and tourist city titles, and many more.

In addition, family relations are also involved in the economic resilience of the community. This is shown through the role of the family not only verbally supporting but manifested in the form of active contributions such as helping the production process, preparing places, helping upload electronic marketing media, and even trading with other relatives. Although not optimal in all indicators of economic resilience, each market has its characteristics in strengthening family economic resilience, namely by supporting which indicators are considered urgent to be implemented immediately.

\section{References}

Adnyani, Ni Ketut Sari, and Dewa Ayu Eka Agustini. "Digitalisasi Sebagai Pemulihan Perekonomian di Sektor Kerja Dalam mendukung Kebangkitan UMKM di Provinsi Bali." Jurnal Pengabdian Masyarakat Media Ganesha Fhis 1, no. 2 (2020).

Ajis. Interview about Digitalization of Creative Markets in Encouraging Family Economic Growth, September 2, 2021

Ansori, Aan. "Digitalisasi Ekonomi Syariah." Islamiconomic: Jurnal Ekonomi Keuangan Dan Bisnis Islam 7, no. 1 (2016).

Azizah, SitiNur, and Muhfiatun. "Pengembangan Ekonomi Kreatif Berbasis Kearifan Lokal Pandanus Handicraft dalam Menghadapi Pasar Modern Perspektif Ekonomi Syariah (Study Case di Pandanus Nusa Sambisari Yogyakarta)." Aplikasia: Jurnal Aplikasi Ilmuilmu Agama 17, no. 2 (February 12, 2018). https://doi.org/10.14421/aplikasia. v17i2.1273. 
Firdausy, Carunia, ed. Strategi Pengembangan Ekonomi Kreatif di Indonesia. Jakarta: Yayasan PustakaObor Indonesia, 2018, Cet. ke-2.

Imron, Ali, and Muhammad Syafa'at. "Revitalisasi Home Industry Berbasis Modal Sosial Sebagai Strategi Ketahanan Ekonomi Menghadapi Pandemi Covid-19," n.d.,

Kharisma, Linang. Interview about Digitalization of Creative Markets in Encouraging Family Economic Growth, September 3, 2021.

Kurnia, Ana. Interview about Digitalization of Creative Markets in Encouraging Family Economic Growth, September 3, 2021.

Martan, Ahmad Jio. Interview about Digitalization of Creative Markets in Encouraging Family Economic Growth, September 4, 2021.

Melan, and Rosa. Interview about Digitalization of Creative Markets in Encouraging Family Economic Growth, September 3, 2021.

Melsya, Novia Shinta. Interview about Digitalization of Creative Markets in Encouraging Family Economic Growth, September 2, 2021.

Menteri Perdagangan Republik Indonesia. Perkembangan Ekonomi Kreatif Indonesia 2025, 2008.

Mita. Interview about Digitalization of Creative Markets in Encouraging Family Economic Growth, September 4, 2021.

Kreatif, BadanEkonomi. Infografis Sebaran Pelaku Ekonomi Kreatif. Jakarta, 2019.

Mulyana, Slamet, Meria Octavianti, and Nadila Zahara Faradysa. "Pengelolaan Media Sosial Sebagai Media Promosi Pasar Digital Cikundul Sukabumi," no. 1 (2019)

Nurrachmi, Intan, Setiawan. "Peran Koperasi Syariah Sebagai Pusat Kegiatan Muamalah Jamaah Masjid (Studi Kasus Koperasi Syariah Baitul Mu'min Komplek Pasir Jati, Desa Jati Endah Kecamatan Cilengkrang Kabupaten Bandung)", Jurnal Ilmiah Mizani, Vol. 7, No. 1 (2020).
Nurakhimah, Atik. Interview with Customers about Digitalization of Creative Markets in Encouraging Family Economic Growth, September 2, 2021.

Pangestu, DR Mari Elka. "Hasil Konvensi Pengembangan Ekonomi Kreatif 20092015," June 2008

Purnomo, Rochmat Aldy. Ekonomi Kreatif: Pilar Pembangunan Indonesia. ZiyadVisi Media, 2016.

Rofaida, Rofi, Suryana, Asti NurAryanti, and Yoga Perdana. "Strategi Inovasi pada Industri Kreatif Digital: Upaya Memperoleh Keunggulan Bersaing pada Era Revolusi Industri 4.0." Jurnal Manajemen dan Keuangan 8, no. 3 (June 11, 2020).

Sari, Anggri Puspita, Muhammad Faisal AR Pelu, Indah Kusuma Dewi, Marthinus Ismail, Robert Tua Siregar, Nina Mistriani, Elisabeth Lenny Marit, et al. Ekonomi Kreatif. Yayasan Kita Menulis, 2020.

Shofa, Ikhwanus. "Pertumbuhan Dan Strategi Pengembangan Ekonomi Kreatif Kota Malang." Jurnal Pangrita 1, no. 1 (2018).

Sholikhatin, SitiAlvi, Wanda Fitrianingsih, and Sahira Dhiyaulhaq. "Pelatihan Digital Marketing Bagi Anggota Nasyiatul Aisyiyah Purbalingga Dalam Menghadapi Era Pasar Global Dan Pengembangan Industri Kreatif" 4 (n.d.).

Yunita. Interview about Digitalization of Creative Markets in Encouraging Family Economic Growth, September 4, 2021.

Zumaroh, "Bisnis Haram Dan Pengaruhnya Terhadap Fisik Dan Psikis Manusia”, Jurnal Ilmiah Mizani, Vol. 4, No. 2 (2017). 